\title{
A Novel Class of Organosoluble and Strictly Alternating Poly(amine-amide-imide)s Containing Triphenylamine Units in the Main Chain
}

\author{
Guey-Sheng LIOU ${ }^{\dagger}$ and Sheng-Huei HSIAO ${ }^{* \dagger}$ \\ Department of Applied Chemistry, National Chi Nan University, 1 University Road Puli, Nantou Hsien 545, \\ Taiwan, Republic of China \\ *Department of Chemical Engineering, Tatung University, 40 Chungshan North Road, 3rd Section, Taipei 104, \\ Taiwan, Republic of China
}

(Received November 28, 2002; Accepted January 30, 2003)

KEY WORDS Poly(amine-amide-imide)s / Triphenylamine Unit / Solubility / Thermal Properties /

Among the various heterocyclic polymers that have been investigated for high-performance applications, aromatic polyimides are used widely in the semiconductor and electronic-packaging industry because of their outstanding thermally stability, good insulation properties with low dielectric constant, good adhesion to common substrates, and superior chemical stability. ${ }^{1,2}$ However, these polymers are generally intractable and lack the properties essential for successful fabrication into useful forms due to their high melting or glass transition temperatures and their limited solubility in organic solvents. Therefore, a great deal of effort has been expended to try to improve the processing characteristics of the relatively intractable polymers. ${ }^{3-8}$ These studies include introducing flexible segments into the polymer chain; replacing symmetrical aromatic rings by unsymmetrical ones, which leads to a reduction in crystallinity; introducing bulky pendant groups to minimize crystallization; and forming a noncoplanar structure, thereby making crystallization impossible. In addition, it is well-known that the synthesis of poly(amide-imide)s can offer a compromise between excellent thermal stability and tractability? On the other hand, incorporation of a bulky pendant phenyl group into a polymer backbone is known to increase solubility and processability of polyimides without sacrificing high thermal stability. ${ }^{10-13}$ Nevertheless, little is known about aromatic polyimides having a phenyl-pendant aromatic amine unit in the polymer backbone, that is, poly(amine-imide)s. The only example was the poly(amine-imide)s derived from 4,4'diaminotriphenylamine and various aromatic tetracarboxylic dianhydrides. ${ }^{14}$

Recently, we have designed new triphenylamine- containing poly(amine-amide)s having 1,4-phenylene backbone to elucidate the effect of backbone structure on properties of poly(amine-amide)s. ${ }^{15}$ This study explores the synthesis and basic characterization of a series of new strictly alternating aromatic poly(amineamide-imide)s containing the triphenylamine unit by the polymerization of $N, N^{\prime}$-bis(4-aminophenyl)- $N, N^{\prime}$ diphenyl-1,4-phenylenediamine ${ }^{15}$ with various imide ring-preformed dicarboxylic acids. It is quite likely that the triphenylamine-containing poly(amine-amideimide)s will possess electro- and photochemical properties as well as high thermal stability because of the triphenylamine conjugated system. Thus, these triphenylamine-containing poly(amine-amide-imide)s may be applied in organic electroluminescent elements because light-emitting triarylamine derivatives $^{16-18}$ and triarylamine-containing polymers ${ }^{19,20}$ are reputed to be a hole-transporting layer material and show increasing potential as active components for a wide range of electronic and optoelectronics devices.

\section{EXPERIMENTAL}

\section{Materials}

According to the methods reported previously, ${ }^{21-24}$ imide-dicarboxylic acids $\mathbf{1 a}$ and $\mathbf{1 b}$ were synthesized by condensation of trimellitic anhydride with glycine and $p$-aminobenzoic acid, respectively, and diimide-dicarboxylic acids 1c-1f were prepared by condensation of corresponding diamines with two equivalent amount of trimellitic anhydride. $N, N^{\prime}$-Bis(4-aminophenyl)- $N, N^{\prime}$-diphenyl1,4-phenylenediamine $(2)\left(\mathrm{mp} 261-262^{\circ} \mathrm{C}\right)$ was synthesized by hydrogen or hydrazine $\mathrm{Pd} / \mathrm{C}$-catalyzed

${ }^{\dagger}$ To whom correspondence should be addressed (E-mail: gsliou@ncnu.edu.tw, shhsiao@ttu.edu.tw). 
reduction of $N, N^{\prime}$-bis(4-nitrophenyl)- $N, N^{\prime}$-diphenyl1,4-phenylenediamine resulting from the condensation of $N, N^{\prime}$-diphenyl-1,4-phenylenediamine with 4fluoronitrobenzene in the presence of potassium carbonate or sodium hydride. The synthetic details of diamine 2 have been reported in a recent paper. ${ }^{15} \mathrm{Com}$ mercially obtained anhydrous calcium chloride was dried under vacuum at $150^{\circ} \mathrm{C}$ for $6 \mathrm{~h}$. Triphenyl phosphite (TPP) was purified by distillation under reduced pressure. Dimethyl sulfoxide (DMSO), $N$-methyl-2pyrrolidone (NMP), $N, N$-demethylformamide (DMF), and pyridine were purified by distillation under reduced pressure over calcium hydride and stored over $4 \AA$ molecular sieves.

\section{General Polymer Synthesis}

Typical procedures for the synthesis of triphenylamine-based poly(amine-amide-imide) $\mathbf{3 g}$ are as follows. A mixture of $0.4426 \mathrm{~g}(1.0 \mathrm{mmol})$ of diamine 2 , $0.5482 \mathrm{~g}(1.0 \mathrm{mmol})$ of the diimide-diacid $1 \mathrm{~g}, 0.4 \mathrm{~g}$ of calcium chloride, $0.7 \mathrm{~mL}$ of TPP, $1.0 \mathrm{~mL}$ of pyridine, and $4 \mathrm{~mL}$ of NMP was heated with stirring at $105^{\circ} \mathrm{C}$ for $3 \mathrm{~h}$. The polymer solution was poured slowly into $300 \mathrm{~mL}$ of stirring methanol giving rise to a stringy, fiber-like precipitate which was collected by filtration, washed thoroughly with hot water and methanol, and dried under vacuum at $100^{\circ} \mathrm{C}$; yield $0.945 \mathrm{~g}(99 \%)$. The inherent viscosity of the obtained poly(amineamide-imide) $3 \mathrm{~g}$ was $0.62 \mathrm{dL} \mathrm{g}^{-1}$, measured at a concentration of $0.5 \mathrm{~g} \mathrm{dL}^{-1}$ in $N, N$-dimethylacetamide (DMAc), containing $5 \mathrm{wt} \% \mathrm{LiCl}$ at $30^{\circ} \mathrm{C}$.

IR (film): 3310 (N-H stretching), 1790, 1720 (imide carbonyl stretching), and $1670 \mathrm{~cm}^{-1}$ (amide carbonyl stretching). ELEM. ANAL. Calcd. for $\left(\mathrm{C}_{60} \mathrm{H}_{38} \mathrm{~N}_{6} \mathrm{O}_{7}\right)_{n}$ (954.99) ${ }_{n}$ : C, 75.46\%; H, 4.01\%; N, 8.80\%. Found: C, $73.29 \%$; H, $4.09 \%$; N, $8.50 \%$.

\section{Preparation of Poly(amine-amide-imide) Films}

A solution of polymer was made by dissolving about $0.7 \mathrm{~g}$ of the poly(amine-amide-imide) sample in $10 \mathrm{~mL}$ of DMAc. The homogenous solution was poured into a $9 \mathrm{~cm}$ glass Petri dish, which was placed in a $90^{\circ} \mathrm{C}$ oven overnight to slowly release the solvent, then the film was stripped off from the glass substrate and further dried in vacuo at $160^{\circ} \mathrm{C}$ for $8 \mathrm{~h}$. The obtained films had about $80-100 \mu \mathrm{m}$ in thickness and were used for X-ray diffraction measurements, tensile tests, solubility tests, and thermal analyses.

\section{Measurements}

Infrared spectra were recorded on a Horiba FT720 Fourier transform infrared spectrometer. Elemental analyses were run in a PerkinElmer model 2400
$\mathrm{C}-\mathrm{H}-\mathrm{N}$ analyzer. The inherent viscosities were determined at a concentration of $0.5 \mathrm{~g} \mathrm{dL}^{-1}$ in DMAc $5 \mathrm{wt} \%$ $\mathrm{LiCl}$ using a Cannon-Fenske viscometer at $30^{\circ} \mathrm{C}$. Thermogravimetric analysis (TGA) was conducted with a PerkinElmer Pyris 1 TGA. Experiments were carried out on 3-5 mg samples heated in flowing nitrogen or air $\left(30 \mathrm{~cm}^{3} \mathrm{~min}^{-1}\right)$ at a heating rate of $20^{\circ} \mathrm{C} \mathrm{min}^{-1}$. Differential scanning calorimetry (DSC) was performed on a PerkinElmer Pyris 1 differential scanning calorimeter in flowing nitrogen $\left(20 \mathrm{~cm}^{3} \mathrm{~min}^{-1}\right)$ at a heating rate of $20^{\circ} \mathrm{C} \mathrm{min}^{-1}$. Thermomechanical analysis (TMA) was conducted with a PerkinElmer TMA 7 at a scan rate of $10^{\circ} \mathrm{C} \mathrm{min}^{-1}$ with a penetration probe of $1.0 \mathrm{~mm}$ diameter under an applied constant load of $10 \mathrm{mN}$. Wideangle X-ray diffractograms were obtained on a Siemens Kristalloflex D5000 X-ray diffractometer, using nickelfiltered copper $K_{\alpha}$ radiation $(40 \mathrm{kV}, 15 \mathrm{~mA})$, and the scanning rate was $2^{\circ} \mathrm{min}^{-1}$. Measurements were performed with film specimens of about $0.1 \mathrm{~mm}$ in thickness. An Instron universal tester model 1130 with a load cell $5 \mathrm{~kg}$ was used to study the stress-strain behavior of the samples. A gauge length of $2 \mathrm{~cm}$ and a crosshead speed of $5 \mathrm{~mm} \mathrm{~min}^{-1}$ were used for this study. Measurements were performed at room temperature with film specimens $(0.5 \mathrm{~cm}$ width, $6 \mathrm{~cm}$ length, and about $0.1 \mathrm{~mm}$ thickness), and an average of at least five individual determinations was used.

\section{RESULTS AND DISCUSSION}

\section{Polymer Synthesis}

A series of new triphenylamine-based poly(amineamide-imide)s $\mathbf{3 a}-\mathbf{3 h}$ were synthesized from diamine 2 with imide-diacids (1a, 1b) and diimide-diacids (1c-1h) by the direct phosphorylation polycondensation reaction using triphenyl phosphite and pyridine as condensing agents (Scheme 1). All the polymerizations proceeded homogeneously throughout the reaction and afforded clear, highly viscous polymer solutions. All the polymers precipitated in a tough fiber-like form when slowly pouring the resulting polymer solutions into stirring methanol. These poly(amine-amideimide)s were obtained in almost quantitative yield with inherent viscosities in the range of $0.37-0.80 \mathrm{dL} \mathrm{g}^{-1}$ measured in DMAc $5 \mathrm{wt} \% \mathrm{LiCl}$, as shown in Table I. Most of the poly(amine-amide-imide)s could be solution cast into flexible and tough films, indicative of the formation of high molecular weight polymers. The formation of poly(amine-amide-imide)s was confirmed by elemental analysis and infrared spectroscopy. Elemental analyses are in a good agreement with the proposed structures, missing only the values found for the Cpercentages that are always lower than the theoretical 
${ }^{\mathrm{HO}} \mathrm{C}_{\mathrm{O}}^{\mathrm{O}}$

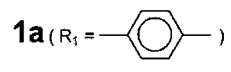

$\mathbf{1} \mathbf{b}_{\left(\mathrm{R}_{1}=-\mathrm{CH}_{2}-\right.}$ )<smiles>O=C(O)c1ccc2c(c1)C(=O)N(NPN1C(=O)c3ccc(C(=O)O)cc3C1=O)C2=O</smiles>

1c $\mathrm{h}$

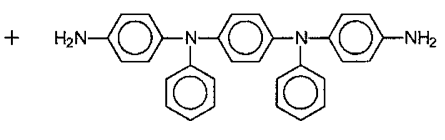

2

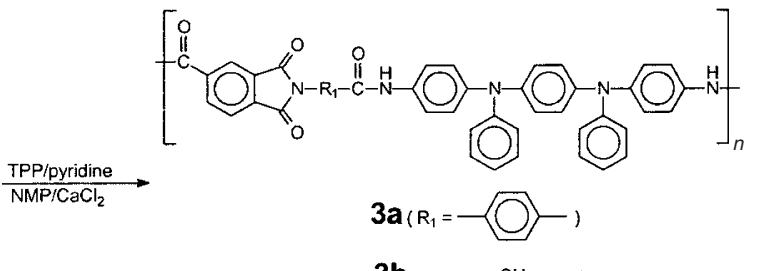

$3 \mathbf{b}\left(\mathrm{R}_{1}=-\mathrm{CH}_{2}-\right.$,

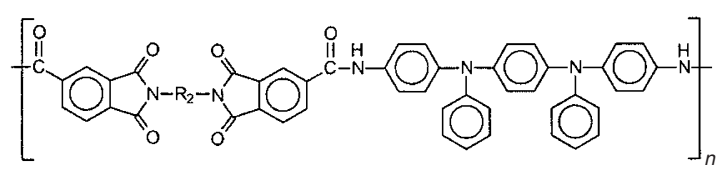

$3 c \sim h$

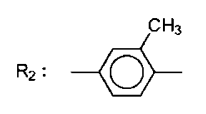

c

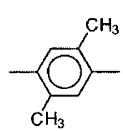

d

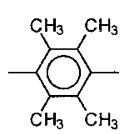

e

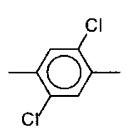

$f$

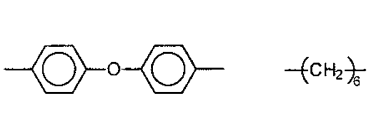

g

h

Scheme 1. Synthesis of triphenylamine-containing poly(amide-imide).

Table I. Inherent viscosity and elemental analysis of poly(amine-amide-imide)s

\begin{tabular}{|c|c|c|c|c|c|c|c|c|}
\hline \multirow{3}{*}{$\begin{array}{l}\text { Polymer } \\
\text { code }\end{array}$} & \multirow{3}{*}{$\begin{array}{c}\eta_{\text {inh }} \\
(\mathrm{dL} g)^{\mathrm{a}}\end{array}$} & \multicolumn{7}{|c|}{ Elemental analysis } \\
\hline & & \multirow{2}{*}{$\begin{array}{c}\text { Formula } \\
\text { (Formula weight) }\end{array}$} & \multicolumn{3}{|c|}{ Calcd (\%) } & \multicolumn{3}{|c|}{ Found (\%) } \\
\hline & & & $\bar{C}$ & $\mathrm{H}$ & $\mathrm{N}$ & $\bar{C}$ & $\mathrm{H}$ & $\mathrm{N}$ \\
\hline $3 \mathbf{a}$ & 0.52 & $\begin{array}{c}\left(\mathrm{C}_{46} \mathrm{H}_{31} \mathrm{~N}_{5} \mathrm{O}_{4}\right)_{n} \\
(717.78)_{n}\end{array}$ & 76.97 & 4.35 & 9.76 & 73.93 & 4.38 & 9.42 \\
\hline $3 \mathbf{b}$ & 0.37 & $\begin{array}{c}\left(\mathrm{C}_{41} \mathrm{H}_{29} \mathrm{~N}_{5} \mathrm{O}_{4}\right)_{n} \\
\quad(655.71)_{n}\end{array}$ & 75.10 & 4.46 & 10.68 & 71.21 & 4.46 & 10.08 \\
\hline $3 c$ & 0.66 & $\begin{array}{c}\left(\mathrm{C}_{55} \mathrm{H}_{36} \mathrm{~N}_{6} \mathrm{O}_{6}\right)_{n} \\
(876.92)_{n}\end{array}$ & 75.33 & 4.14 & 9.58 & 71.87 & 4.12 & 9.15 \\
\hline 3d & 0.60 & $\begin{array}{c}\left(\mathrm{C}_{56} \mathrm{H}_{38} \mathrm{~N}_{6} \mathrm{O}_{6}\right)_{n} \\
(890.95)_{n}\end{array}$ & 75.49 & 4.30 & 9.43 & 72.46 & 4.64 & 8.85 \\
\hline $3 e$ & 0.80 & $\begin{array}{l}\left(\mathrm{C}_{58} \mathrm{H}_{42} \mathrm{~N}_{6} \mathrm{O}_{6}\right)_{n} \\
\quad(919.00)_{n}\end{array}$ & 75.80 & 4.61 & 9.14 & 73.01 & 4.76 & 8.85 \\
\hline $3 \mathbf{f}$ & 0.60 & $\begin{array}{c}\left(\mathrm{C}_{54} \mathrm{H}_{32} \mathrm{Cl}_{2} \mathrm{~N}_{6} \mathrm{O}_{6}\right)_{n} \\
(931.79)_{n}\end{array}$ & 69.61 & 3.46 & 9.02 & 67.14 & 3.52 & 8.74 \\
\hline $3 g$ & 0.62 & $\begin{array}{c}\left(\mathrm{C}_{60} \mathrm{H}_{38} \mathrm{~N}_{6} \mathrm{O}_{7}\right)_{n} \\
(954.99)_{n}\end{array}$ & 75.46 & 4.01 & 8.80 & 73.29 & 4.09 & 8.50 \\
\hline $3 \mathbf{h}$ & 0.46 & $\begin{array}{c}\left(\mathrm{C}_{54} \mathrm{H}_{42} \mathrm{~N}_{6} \mathrm{O}_{6}\right)_{n} \\
(870.96)_{n}\end{array}$ & 74.47 & 4.86 & 9.65 & 72.72 & 4.92 & 9.56 \\
\hline
\end{tabular}

${ }^{a}$ Measured at a concentration of $0.5 \mathrm{~g} \mathrm{dL}^{-1}$ in DMAc $5 \mathrm{wt} \% \mathrm{LiCl}$ at $30^{\circ} \mathrm{C}$.

ones. That certainly can be attributed to the very aromatic nature of these polymers, which commonly leave a small coal residue in the standard conditions of microanalysis. The IR spectra of the poly(amine-amideimide)s exhibited characteristic absorptions for imide ring at around 1790 and $1720 \mathrm{~cm}^{-1}$, characteristic of the symmetrical and asymmetrical carbonyl stretching vibration. Bands of amide groups appeared at near 3400$3300 \mathrm{~cm}^{-1}(\mathrm{~N}-\mathrm{H})$ and $1670 \mathrm{~cm}^{-1}(\mathrm{C}=\mathrm{O})$, supported the formation of the amide linkages.

\section{Properties of Polymers}

The X-ray diffraction studies of the triphenylaminebased poly(amine-amide-imide)s indicated that all the polymers were essentially amorphous. The solubility behavior of these polymers was tested qualitatively, and the results are listed in Table II. All the poly(amineamide-imide)s were soluble in polar solvents such as NMP, DMAc, and DMF. Most of them were also soluble in $m$-cresol and hot DMSO. Their high solubility and amorphous nature can be attributed to the introduction of bulky, twisted, three-dimensional triphenylamine unit along the polymer backbone, which resulted in increased chain distance and decreased chain interaction. Thus, the excellent solubility makes the present polymers potential candidates for practical applications in spin-on and casting processes.

As mentioned above, Most of the poly(amine-amide- 
Poly(amine-amide-imide)s Containing Triphenylamine Units

Table II. Solubility and thin film tensile properties of poly(amine-amide-imide)s

\begin{tabular}{|c|c|c|c|c|c|c|c|c|c|c|}
\hline \multirow{3}{*}{ Polymer } & \multicolumn{7}{|c|}{ Solubility $^{\mathrm{a}}$} & \multicolumn{3}{|c|}{ Tensile properties of the polymer films ${ }^{b}$} \\
\hline & NMP & DMAc & DMF & DMSO & $m$-Cresol & THF & $\mathrm{CHCl}_{3}$ & Tensile strength & $\underline{\text { Elongation to break }}$ & $\underline{\text { Initial modulu }}$ \\
\hline & NIVII & & DIVIT & DIVISU & & 1ПГГ & $\mathrm{CHCl}_{3}$ & $\mathrm{MPa}$ & $\%$ & $\mathrm{GPa}$ \\
\hline $3 \mathbf{a}$ & + & + & + & $+\mathrm{h}$ & - & - & - & 113 & 12 & 2.6 \\
\hline $\mathbf{3 b}$ & + & + & + & + & - & - & - & - & - & - \\
\hline $3 \mathrm{c}$ & + & + & $+\mathrm{h}$ & $+\mathrm{h}$ & + & - & - & 90 & 10 & 2.4 \\
\hline 3d & + & + & + & $+\mathrm{h}$ & + & - & - & 96 & 7 & 2.4 \\
\hline $3 e$ & + & + & + & $+\mathrm{h}$ & + & - & - & 104 & 33 & 1.8 \\
\hline $3 f$ & $+\mathrm{h}$ & $+\mathrm{h}$ & $+\mathrm{h}$ & + & - & + & - & - & - & - \\
\hline $3 g$ & + & + & + & $+\mathrm{h}$ & - & - & - & 107 & 11 & 2.1 \\
\hline $3 \mathrm{~h}$ & + & + & $+\mathrm{h}$ & - & $+\mathrm{h}$ & - & - & 101 & 10 & 2.1 \\
\hline
\end{tabular}

${ }^{a}+$, Soluble at room temperature; $+\mathrm{h}$, soluble on heating; and -, insoluble even on heating. ${ }^{b}$ Films were cast by slow evaporation of polymer solutions in DMAc. The film specimens were dried in vacuo at $160^{\circ} \mathrm{C}$ for $8 \mathrm{~h}$ prior to the tensile test.

Table III. Thermal properties of poly(amine-amide-imide)s

\begin{tabular}{|c|c|c|c|c|c|c|c|}
\hline \multirow{2}{*}{ Polymer } & \multirow{2}{*}{$\begin{array}{c}T_{\mathrm{g}} \\
\left({ }^{\circ} \mathrm{C}\right)^{\mathrm{a}}\end{array}$} & \multirow{2}{*}{$\begin{array}{c}T_{\mathrm{s}} \\
\left({ }^{\circ} \mathrm{C}\right)^{\mathrm{b}}\end{array}$} & \multicolumn{2}{|c|}{$T_{\mathrm{d}}$ at $5 \%$ weight $\operatorname{loss}\left({ }^{\circ} \mathrm{C}\right)^{\mathrm{c}}$} & \multicolumn{2}{|c|}{$T_{\mathrm{d}}$ at $10 \%$ weight loss $\left({ }^{\circ} \mathrm{C}\right)^{\mathrm{c}}$} & \multirow{2}{*}{$\begin{array}{c}\text { Char yield }^{\mathrm{d}} \\
(\text { wt } \%)\end{array}$} \\
\hline & & & In $\mathrm{N}_{2}$ & In air & $\operatorname{In~} N_{2}$ & In air & \\
\hline $3 \mathbf{a}$ & 296 & 295 & 493 & 498 & 572 & 564 & 74 \\
\hline $3 \mathbf{b}$ & 243 & 244 & 416 & 409 & 466 & 465 & 69 \\
\hline $3 c$ & 296 & 299 & 497 & 491 & 576 & 551 & 72 \\
\hline 3d & 285 & 283 & 488 & 485 & 542 & 539 & 70 \\
\hline $3 e$ & 306 & 310 & 498 & 492 & 566 & 546 & 72 \\
\hline $3 f$ & 270 & 257 & 432 & 444 & 520 & 522 & 66 \\
\hline $3 g$ & 290 & 287 & 528 & 518 & 607 & 587 & 73 \\
\hline $3 h$ & 220 & 217 & 460 & 442 & 491 & 482 & 67 \\
\hline
\end{tabular}

${ }^{\mathrm{a}}$ Glass-transition temperature, taken as the midpoint temperature of the baseline shift on the second DSC heating trace

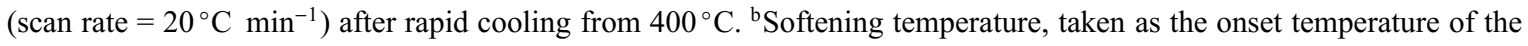
probe displacement on the TMA trace at a heating rate of $10^{\circ} \mathrm{C} \mathrm{min}^{-1}$. The film samples were heated at $300^{\circ} \mathrm{C}$ for $30 \mathrm{~min}$ prior to the TMA experiments. ${ }^{\circ}$ Decomposition temperature, recorded via TGA at a heating rate of $20^{\circ} \mathrm{C} \mathrm{min}^{-1}$ and a gas-flow rate of $30 \mathrm{~cm}^{3} \mathrm{~min}^{-1}$. ${ }^{\mathrm{d}}$ Residual weight percentage at $800^{\circ} \mathrm{C}$ in nitrogen.

imide)s could be solution-cast into smooth, flexible, and tough films. These films were subjected to tensile testing, and the results are also given in Table II. The tensile strengths, elongations to break, and initial moduli of these films were in the ranges of $90-113 \mathrm{MPa}$, $7-33 \%$, and 1.8-2.6 GPa, respectively.

DSC and TMA were used to evaluate the thermal transitions of these poly(amine-amide-imide)s. Each sample was subjected to two subsequent DSC heating runs with $20^{\circ} \mathrm{C} \mathrm{min}^{-1}$, the first from 40 to $400^{\circ} \mathrm{C}$ after which the sample was cooled down with a programmed cooling rate of $-200{ }^{\circ} \mathrm{C} \mathrm{min}^{-1}$ to $40^{\circ} \mathrm{C}$, followed by a second heating run with an end temperature of $400{ }^{\circ} \mathrm{C}$. The first run was aimed to eliminate any possible volatiles such as the absorbed moisture and the residual solvent in the samples. The quenching procedure led to predominantly amorphous samples. Reheating produced neat DSC thermograms in the second run, and a clear heat capacity jump attributable to a glass transition could be observed in every case. As shown in Table III, the poly(amineamide-imide)s $3 \mathbf{a}-\mathbf{3 h}$ had $T_{\mathrm{g}}$ 's of $220-306^{\circ} \mathrm{C}$, follow- ing the decreasing order of chain flexibility. As expected, the semi-aromatic poly(amine-amide-imide) $\mathbf{3 h}$ revealed the lowest $T_{\mathrm{g}}$ of $200^{\circ} \mathrm{C}$ because of the flexible hexamethylene unit. All the polymers showed no welldefined melting endotherms up to the decomposition temperatures on the DSC thermograms. This result also supports the amorphous nature of these triphenylaminecontaining poly(amine-amide-imide)s. The softening temperatures $\left(T_{\mathrm{S}}\right)$ (may be referred as apparent $T_{\mathrm{g}}$ ) of the poly(amine-amide-imide) film samples were determined by the TMA method using a loaded penetration probe and were taken from the onset temperatures of the probe displacement on the TMA traces. In almost all cases, the $T_{\mathrm{s}}$ values obtained by TMA are comparable to the $T_{\mathrm{g}}$ values measured by the DSC experiments.

The thermal stability of these poly(amine-amideimide)s was studied by TGA. Some thermal behavior data determined from original thermograms poly(amine-amide-imide) 3 in both air and nitrogen atmospheres are also tabulated in Table III. The wholly aromatic poly(amine-amide-imide)s showed good thermal stability, with $10 \%$ weight loss temperature being 
recorded above $522^{\circ} \mathrm{C}$ in air or nitrogen. As expected, the polymers containing aliphatic segments, such as polymers $\mathbf{3 b}$ and $\mathbf{3 h}$, revealed a lower thermal stability; they began to decompose around $400^{\circ} \mathrm{C}$. The amount of carbonized residue (char yield) at $800^{\circ} \mathrm{C}$ of these poly(amine-amide-imide)s in nitrogen atmosphere was $66-74 \%$, indicating high flame-retardant characteristics. It also can be noticed that there is a large window between $T_{\mathrm{g}}$ or $T_{\mathrm{s}}$ and the decomposition temperature of each poly(amine-amide-imide), which could be advantageous in the processing of these polymers by thermoforming technique.

\section{CONCLUSIONS}

A series of new triphenylamine-containing aromatic poly(amine-amide-imide)s have been successfully synthesized by the direct phosphorylation polycondensation reaction from the diamine, $N, N^{\prime}$-bis(4aminophenyl)- $N, N^{\prime}$-diphenyl-1,4-phenylenediamine, and various imide ring-preformed dicarboxylic acids. Because of the presence of the bulky triphenylamine unit, all the poly(amine-amide)s were amorphous, had good solubility in many polar aprotic solvents, and exhibited excellent thin film forming capability. Good solubility, moderate $T_{\mathrm{g}}$ or $T_{\mathrm{s}}$ values suitable for molding, and good thermal stability and mechanical properties make these triphenylamine-based poly(amine-amide-imide)s as promising processable high-performance polymeric materials.

Acknowledgment. The authors are grateful to the National Science Council of the Republic of China for financial support of this work (Grant NSC 91-2216-E260-001).

\section{REFERENCES}

1. M. K. Ghosh, K. L. Mittal, Ed., "Polyimides: Fundamentals and Applications" Marcel Dekker, New York, N.Y., 1996, pp 309-341.

2. D. Wilson, H. D. Stenzenberger, P. M. Hergenrother, Ed.,
"Polyimides" Chapman and Hall, New York, N.Y., 1990, pp 227-251.

3. Y. Imai, N. N. Maldar, and M. Kakimoto, J. Polym. Sci., Polym. Chem. Ed., 22, 2189 (1984).

4. Y. Imai, React. Funct. Polym., 30, 3 (1996).

5. S. H. Hsiao, G. S. Liou, and S. H. Chen, J. Polym. Sci. Part A: Polym. Chem., 36, 1657 (1998).

6. G. S. Liou, J. Polym. Sci. Part. A: Polym. Chem., 36, 1937 (1998).

7. G. S. Liou, M. Maruyama, M. Kakimoto, and Y. Imai, J. Polym. Sci. Part A: Polym. Chem., 36, 2021 (1998).

8. S. H. Hsiao and C. T. Li, Macromolecules, 31, 7213 (1998).

9. (a) C. P. Yang, G. S. Liou, C. C. Yang, and N. W. Tseng, Polym. Bull., 42, 1 (1999).

(b) C. P. Yang, G. S. Liou, C. C. Yang, and S. H. Chen, Polym Bull., 43, 21 (1999).

(c) C. P. Yang, G. S. Liou, S. Y. Chang, and S. H. Chen, J. Appl. Polym. Sci., 73, 271 (1999).

10. Y. Imai, N. N. Maldar, and M. Kakimoto, J. Polym. Sci. Polym. Chem. Ed., 22, 2189 (1984).

11. H. J. Jeong, M. Kakimoto, and Y. Imai, J. Polym. Sci. Part A: Polym. Chem., 29, 39 (1991).

12. H. J. Jeong, M. Kakimoto, and Y. Imai, J. Polym. Sci. Part A: Polym. Chem., 29, 1691 (1991).

13. G. S. Liou and S. H. Hsiao, J. Polym. Sci. Part A: Polym. Chem., 40, 2564 (2002).

14. Y. Oishi, M. Ishida, M. Kakimoto, Y. Imai, and T. Kurosaki, J. Polym. Sci. Part A: Polym. Chem., 30, 1027 (1992).

15. G. S. Liou, S. H. Hsiao, M. Ishida, M. Kakimoto, and Y. Imai, J. Polym. Sci. Part A: Polym. Chem., 40, 2810 (2002).

16. C. W. Ko and Y. T. Tao, Synth. Met., 126, 37 (2002).

17. B. E. Koene, D. E. Loy, and M. E. Thompson, Chem. Mater., 10, 2235 (1998).

18. Y. Shirota, K. Okumoto, and H. Inada, Synth. Met., 111-112, 387 (2000).

19. A. Wu, M. Kakimoto, and Y. Imai, Supramol. Sci., 3, 3 (1996).

20. J. Lu, A. R. Hlil, Y. Sun, and A. S. Hay, Chem Mater, 11, 2501 (1999).

21. C. P. Yang and S. H. Hsiao, Makromol. Chem., 190, 2199 (1989).

22. S. H. Hsiao and C. P. Yang, J. Polym. Sci. Part A: Polym. Chem., 28, 1149 (1990).

23. G. S. Liou, J. Polym. Sci. Part A: Polym. Chem., 37, 4141 (1999).

24. G. S. Liou, Macromol. Chem. Phys., 201, 1141 (2000).

25. N. Yamazaki, M. Matsumoto, and F. Higashi, J. Polym. Sci. Polym. Chem. Ed., 13, 1373 (1975). 